\title{
Proceeding
}

Supplementary Issue: Winter Conferences of Sports Science. VI International Congress and XXVII National Congress of Physical

Education, 23-25 October 2019. Palma (Baleares), Spain.

\section{Relationship between the use of video games and physical-healthy, psychosocial and academic indicators in primary schoolchildren}

\author{
GABRIEL GONZÁLEZ-VALERO, JOSÉ LUIS UBAGO-JIMÉNEZ², IRWIN ANDRÉS RAMÍREZ-GRANIZO², \\ PILAR PUERTAS-MOLERO2 \\ ${ }^{1}$ Department of Didactics of Musical, Artistic and Corporal Expression, Research Group HUM-238, University \\ of Jaen, Spain \\ ${ }^{2}$ Department of Didactics of Musical, Artistic and Corporal Expression, Research Group HUM-238, University \\ of Granada, Spain
}

\begin{abstract}
The use of different digital devices is a widespread practice among young people. These acts will be a key conditioning factor in their health and quality of life. Therefore, the purpose of the study is to establish the relationships between the problematic use of video games with physical-healthy and psychosocial variables in Primary Education students. This study is descriptive and cross-sectional in nature, developed in a sample of 577 primary schoolchildren, aged between 11-12 years $(\mathrm{M}=11.41$; S.D. = 0.492). An Ad-Hoc questionnaire was used to record hours of physical activity, hours of sleep and use of screens. Likewise, for the problematic use with video games, the Questionnaire of Experiences Related to Video Games (CESR) was used, as well as the questionnaire of Adherence to the Mediterranean Diet (KIDMED). Those young people who register more hours of sleep and more hours of physical activity, do not offer problems with video games. However, the higher values of use of digital screens are related to severe problems. Those students who do not have problems with video games obtain higher values at academic, emotional, family and physical levels. In contrast, higher values of social self-concept are associated with severe problems. Finally, higher body mass indices are associated with severe problems with video games, while greater adherence to the Mediterranean diet is associated with those who do not have problems.
\end{abstract}

Keywords: Video games; Self-concept; Healthy habits; Students.

Cite this article as:

González-Valero, G., Ubago-Jiménez, J.L., Ramírez-Granizo, I.A., \& Puertas-Molero, P. (2020). Relationship between the use of video games and physical-healthy, psychosocial and academic indicators in primary schoolchildren. Journal of Human Sport and Exercise, 15(2proc), S336-S344. doi:https://doi.org/10.14198/ihse.2020.15.Proc2.25

Corresponding author. Department of Didactics of Musical, Artistic and Corporal Expression, University of Granada, 1807, Granada. Spain. https://orcid.org/0000-0001-8878-7677

E-mail: pilarpuertas@correo.ugr.es

Supplementary Issue: Winter Conferences of Sports Science. VI International Congress and XXVII National Congress of Physical Education, 23-25 October 2019. Palma (Baleares), Spain.

JOURNAL OF HUMAN SPORT \& EXERCISE ISSN 1988-5202

(c) Faculty of Education. University of Alicante

doi:10.14198/jhse.2020.15.Proc2.25

S336 $|2020|$ Proc2 | VOLUME 15

C 2020 University of Alicante 


\section{INTRODUCTION}

The development of healthy habits at an early age is essential to promote the integral development of the youngest. Nevertheless, several studies indicate that changes in eating habits, as well as the explosion of new technologies, have caused an increase in problems in society, most of which are derived from sedentary habits (Chacón-Cuberos, Castro-Sánchez, González-Campos and Zurita-Ortega, 2018; González-Valero et al., 2018; Ng et al., 2014).

In this sense, it is of special interest to develop healthy living habits in the youngest, with regular and continued physical activity being one of the most fundamental elements in shaping these habits (Solis-García and Borja-González, 2019; Zurita-Ortega et al., 2018). PA has positive repercussions on a physical level, such as the decrease in fat mass, on a cognitive level, which favours the development of self-esteem and empathy, and on a socio-affective level, which favours the respect of the others, as well as the improvement of social relations (Rosen, et al., 2014; González-Valero, Ubago-Jiménez, Ramírez-Granizo and PuertasMolero, 2019).

It should also be noted that another key factor which contributes to developing healthy habits is sleep. This is essential in childhood, as it contributes to cognitive development (Keller, Haak, DeWall, and Renzetti, 2019). Similarly, it has been shown that during sleep neuronal waste that accumulates during wakefulness is eliminated, which facilitates proper cognitive functioning, increased emotional state and strengthening of the immune system (Mireku et al., 2019).

Similarly, within healthy habits the development of a balanced dietary pattern is essential in order to avoid the appearance of certain pathologies such as obesity or diabetes among others (González-Valero, ZuritaOrtega, Chacón-Cuberos and Puertas-Molero, 2019). In this sense, it is of real importance that children will adhere to the Mediterranean diet in order to create habits that are later extrapolated to their adult age (González-Valero et al., 2017; San Román-Mata, 2019).

All the aspects mentioned above are essential for the development of health-promoting habits, which are closely related to the correct development of self-concept (Espejo-Garcés et al., 2018). During the childhood stage this factor is consolidated, having such importance that it will later influence behaviour during adulthood. As Fuentes, García, García and Lila (2011) state, the self-concept is built, varies and nuanced with the experiences that each person lives. This shows that the development of healthy habits will favour the subsequent construction of personal identity.

Given the many problematic situations and challenges currently facing society, the aim of this study is to analyse the relationship between the problematic use of video games, healthy habits (adherence to the Mediterranean diet, sleep hours, physical activity and BMI), psychosocial habits (self-concept) and screen time in primary school children in the province of Granada.

\section{MATERIAL AND METHOD}

\section{Participants}

A descriptive and cross-sectional study was carried out on a sample of 577 students of Primary Education in Granada (Spain), of which 56.8\% ( $N=328$ ) were male and 43.2\% ( $N=249)$ female, aged between 11 and 12 years $(M=11.41 \pm 0.492)$. 


\section{Variables and instruments}

Ad-Hoc Questionnaire. It was used to register sex categorized in boys and girls, age, daily physical activity practice, daily sleeping hours and daily use of digital screens.

Adherence to the Mediterranean diet (KIDMED)

Developed by Serrá-Majem et al. (2004). It is composed of 16 items of a dichotomic type. It should be noted that the Mediterranean diet is categorized as follows: low (between -4 and 0 points), medium (between 1 and 6 points) and high (between 7 and 12 points). Original scale showed an internal reliability of $a=.86$.

Questionnaire of Experiences Related to Videogames (CESR)

Developed by Chamarro et al. (2014). The instrument consists of 17 items and is categorized as follows: No problem (between 17 and 25 points), potential problems (between 26 and 38) and severe problems (between 39 and 68 points). Reliability of the scale was $\alpha=.87$.

Body Mass Index

The bioimpedance scale and the Seca 206 tape measure were used. Once the data were collected, the classification of the ENKID study (Serra-Majem and Aranceta-Batrina, 2000) was applied, and this construct was classified into four levels: underweight, normal weight, overweight and obesity.

\section{Procedure}

Before the collection of data, a meeting was arranged with the directors and chiefs of studies of the different primary education centres in Granada, in order to explain the nature and aim of the research, providing them with the legal and justifying permits.

Then, the informed consent of the students' legal tutors was given, and only those students who provided the completed form participated in the study. The research was carried out during school time, always in the presence of both the researchers and the academic tutors.

It should be pointed out that the study followed the ethical principles proposed in the Declaration of Helsinki, in which anonymity and confidentiality of the data extracted from all the participants was assured.

\section{Data analysis}

For the analysis of the data, the statistical program SPSS in version 22.0 (IBM Corp, Armonk, NY, USA) for Windows was used. Means, frequencies and standard deviations were used for the descriptions. And for the relational study the ANOVA test was used. To determine the significance of the variables studied, the Pearson Chi-square statistic was used.

\section{RESULTS}

For the following table, statistically significant results were found $(p \leq .05)$ on the relationships of problematic use of video games with hours of physical activity, hours in front of the screen and sleeping hours. The students that showed a higher number of hours of physical activity $(3.10 \pm 0.736)$ and sleeping hours (10.22 $\pm 0.585)$, were associated with those that did not show problems with video games. On the other hand, a greater number of hours in front of the screens $(3.07 \pm 0.769)$ is associated with severe problems with video games. 
Table 1. Physical activity time, screen and sleep according to video games problems.

\begin{tabular}{cccccc}
\hline & Videogames & Media & $\begin{array}{c}\text { Standard } \\
\text { deviation }\end{array}$ & $\mathbf{F}$ & $\mathbf{X}^{2}$ \\
\hline Hours of daily & No problems & 3.10 & 0.736 & & \\
physical activity & Potential problems & 2.44 & 0.899 & 3.846 & $.039^{*}$ \\
& Severe problems & 2.35 & 0.757 & & \\
Screen time & No problems & 2.40 & 0.760 & & \\
& Potential problems & 2.50 & 0.820 & 4.661 & $.021^{*}$ \\
& Severe problems & 3.07 & 0.769 & & \\
Sleep time & No problems & 10.22 & 0.585 & & \\
& Potential problems & 9.96 & 0.535 & 13.328 & $.000^{* *}$ \\
& Severe problems & 9.50 & 0.576 & & \\
\hline
\end{tabular}

In the table below, self-concept is related to problems with video games with significance levels of $p \leq .05$. The highest average values recorded for Academic Self-concept (4.34 \pm 0.468$)$, Emotional Self-concept (3.54 \pm 0.682$)$, Family Self-concept (4.69 \pm 0.315$)$ and Physical Self-concept $(4.25 \pm 0.315)$, are associated with those students who do not have problems with video games. For the Social Self-concept, it is highlighted that the students who present higher levels $(4.33 \pm 0.584)$ are related to severe problems with video games.

Table 2. Self-concept according to the problems with video games.

\begin{tabular}{cccccc}
\hline & Videogames & Media & $\begin{array}{c}\text { Standard } \\
\text { deviation }\end{array}$ & $\mathbf{F}$ & $\mathbf{X}^{2}$ \\
\hline \multirow{3}{*}{ ASC } & No problems & 4.34 & 0.468 & & \\
& Potential problems & 4.20 & 0.501 & 30.298 & $.000^{* *}$ \\
& Severe problems & 3.00 & 0.495 & & \\
SSC & No problems & 4.30 & 0.557 & & \\
& Potential problems & 3.87 & 0.601 & 24.258 & $.000^{* *}$ \\
& Severe problems & 4.33 & 0.584 & & \\
ESC & No problems & 3.54 & 0.682 & & \\
& Potential problems & 3.42 & 0.638 & 5.035 & $.007^{*}$ \\
& Severe problems & 2.83 & 0.676 & & \\
FSC & No problems & 4.69 & 0.315 & & \\
& Potential problems & 4.66 & 0.286 & 4.298 & $.014^{*}$ \\
& Severe problems & 4.59 & 0.310 & & \\
& No problems & 4.25 & 0.454 & & \\
& Potential problems & 3.78 & 0.647 & 41.921 & $.000^{* *}$ \\
& Severe problems & 3.66 & 0.524 & & \\
\hline
\end{tabular}

Note1: Academic Self-concept (ASC), Social Self-concept (SSC), Emotional Self-concept (ESC), Family Self-concept (FSC) and Physical Self-concept (PSC).

The following table shows that the highest average Body Mass Index values for school children $(25.69 \pm$ 2.402) are significantly associated $(p=.000)$ with severe problems with video games. In contrast, better levels of adherence to the Mediterranean Diet $(29.03 \pm 1.932)$ are significantly related $(p=.000)$ to those students who do not have problems. 
Table 3. BMI and AMD according to video games problems.

\begin{tabular}{cccccc}
\hline & Videogames & Media & $\begin{array}{c}\text { Standard } \\
\text { deviation }\end{array}$ & $\mathbf{F}$ & $\mathbf{X}^{2}$ \\
\hline \multirow{3}{*}{ BMI } & No problems & 17.98 & 2.324 & & \\
& Potential problems & 18.02 & 1.986 & 40.249 & $.000^{* *}$ \\
& Severe problems & 25.69 & 2.402 & & \\
AMD & No problems & 29.03 & 2.034 & & \\
& Potential problems & 28.36 & 1.168 & 10.931 & $.000^{* *}$ \\
& Severe problems & 27.41 & 1.932 & & \\
\hline & Note1: Body Max Index (BMI) and Adherence to Mediterranean Diet (AMD).
\end{tabular}

Finally, table 4 shows the relationship between Body Mass Index categories and adherence to the Mediterranean Diet with problems with video games. Those subjects who presented a high ADM ( $N=232$; $49.5 \%$ ) are who do not present problems with video games, instead, $71.4 \%$ of students who have severe problems, present a low ADM.

On the other hand, $100 \%$ of the students who have severe problems with video games $(\mathrm{N}=7)$ show parameters of obesity.

Table 4. Relationship between BMI and AMD categories according to video games problems.

\begin{tabular}{|c|c|c|c|c|c|c|c|c|}
\hline \multirow{2}{*}{$\begin{array}{l}\text { Videogames } \\
\text { problems }\end{array}$} & \multirow{2}{*}{$\begin{array}{c}\text { Total } \\
(\mathrm{N}=577)\end{array}$} & \multicolumn{3}{|c|}{ AMD (KIDMED) } & \multicolumn{4}{|c|}{ BMI } \\
\hline & & Low & Medium & High & $\begin{array}{l}\text { Low } \\
\text { weight }\end{array}$ & $\begin{array}{c}\text { Standard } \\
\text { weight }\end{array}$ & Overweight & Obesity \\
\hline $\begin{array}{c}\text { No problems } \\
\mathrm{N}(\%)\end{array}$ & $\begin{array}{c}469 \\
(81,3 \%)\end{array}$ & $\begin{array}{c}97 \\
(20,7 \%)\end{array}$ & $\begin{array}{c}140 \\
(29,9 \%)\end{array}$ & $\begin{array}{c}232 \\
(49,5 \%)\end{array}$ & $\begin{array}{c}14 \\
(3,0 \%)\end{array}$ & $\begin{array}{c}397 \\
(84,6 \%)\end{array}$ & $\begin{array}{c}58 \\
(12,4 \%)\end{array}$ & $\begin{array}{c}0 \\
(0,0 \%)\end{array}$ \\
\hline $\begin{array}{c}\text { Potential } \\
\text { problems } \\
\mathrm{N}(\%)\end{array}$ & $\begin{array}{c}101 \\
(17,5 \%)\end{array}$ & $\begin{array}{c}21 \\
(20,8 \%)\end{array}$ & $\begin{array}{c}55 \\
(54,5 \%)\end{array}$ & $\begin{array}{c}25 \\
(24,8 \%)\end{array}$ & $\begin{array}{c}0 \\
(0,0 \%)\end{array}$ & $\begin{array}{c}87 \\
(86,1 \%)\end{array}$ & $\begin{array}{c}14 \\
(13,9 \%)\end{array}$ & $\begin{array}{c}0 \\
(0,0 \%)\end{array}$ \\
\hline \multirow[t]{2}{*}{$\begin{array}{c}\text { Severe } \\
\text { problems } \\
\mathrm{N}(\%)\end{array}$} & $7(1,2 \%)$ & $\begin{array}{c}5 \\
(71,4 \%)\end{array}$ & $\begin{array}{c}2 \\
(28,6 \%)\end{array}$ & $\begin{array}{c}0 \\
(0,0 \%)\end{array}$ & $\begin{array}{c}0 \\
(0,0 \%)\end{array}$ & $\begin{array}{c}0 \\
(0,0 \%)\end{array}$ & $\begin{array}{c}0 \\
(0,0 \%)\end{array}$ & $\begin{array}{c}7 \\
(100 \%)\end{array}$ \\
\hline & & \multicolumn{3}{|c|}{$p=.023^{*}$} & \multicolumn{4}{|c|}{$p=.000^{* *}$} \\
\hline
\end{tabular}

\section{DISCUSSION}

Currently, the abusive use of new technologies at an early age, as well as playing with video games is a reality and an act that is increasingly present. These behaviours are leading to increasingly sedentary habits and lifestyles, which affect both the physical-healthy level, as well as the psychological and social. Therefore, this research aims to establish the relationships between the problematic use of video games with physicalhealthy variables such as hours of physical activity, hours of sleep, adherence to the Mediterranean diet and body mass index, as well as with psychosocial aspects such as self-concept and screen use in Elementary Education students. Research of a similar nature exists, in which relationships with other study variables and in different populations are exposed (Aguilar, Vergara, Velásquez and García-Hermoso, 2015; BarrAnderson, Cook, Loth and Neumark-Sztainer, 2018; Espejo-Garcés et al., 2018). 
Increased hours of physical activity and sleep are associated with fewer problems with video games. The variety of activities that young people do in their leisure time, such as being with their peers and playing sports, helps the healthy development of body and mind, as well as reducing problems with the use of digital screens (Barr-Anderson et al., 2018; Graves, Stratton, Ridgers and Cable, 2007). A number of studies have found a negative impact of electronic media on sleep in young people, particularly on the delay of bedtime and duration (Ogunleye, Voss and Sandercock, 2014; Yen, Ko, Yen and Cheng, 2008). Some of the various mechanisms that explain this fact include a greater physiological activation that makes it more difficult to relax at bedtime, as well as the fact that the bright light of the screens favours a delay in the circadian rhythm (Higuchi, Motohashi, Liu and Maeda, 2005).

This relationship is characterised by a clear temporal variable, since young people who decide to spend their leisure time in physical-sports activities or rest, occupy that time which could be spent playing video games or using technological devices. In contrast, severe problems with video games are associated with more time in front of the screens (Chacón-Cuberos et al., 2018). The current availability in households of devices such as mobile phones, tablets, televisions and computers, increases the number of hours in front of the screens of these devices and therefore, the possibility that subjects spend their time playing different types of video games.

A better self-perception in the academic and family environment, as well as with the emotional and physical state, is associated with students who do not have problems with video games. In relation to video game consumption habits, it turned out that students who have never played or play moderately, have a greater academic self-concept (Espejo-Garcés et al., 2018). High use of screen devices can generate low levels of self-esteem, self-concept and poor academic performance, although it has been shown that high use of mobile phones is positively related to social self-concept (McKay, Sumnall, Cole and Percy, 2012; Šporčić and Glavak-Tkalić, 2018). Not abusing video games enables students to use their time to do homework, share it with their families and be physically active in their extracurricular activities. Also, playing video games has implicit feelings such as frustration for not winning, which can generate negative emotions (ChacónCuberos, Zurita-Ortega, Castro-Sánchez and Espejo-Garcés, 2018).

Therefore, high values in the social self-concept of young people are related to severe problems with video games. This association takes weight due to social networks and the possibility of playing online with users from anywhere in the world. The feeling of being part of a group and establishing connections between a group of peers in the same, is derived to a second level, because more and more young people establish social ties through chats of the games themselves or the social networks associated to them, hence the need to play games or use social networks to feel socially fulfilled (Chacón-Cuberos et al., 2018; Ramírez-Granizo et al., 2020; Šporčić and Glavak-Tkalić, 2018).

The highest BMI values are related to severe problems with video games. Most video games, except exergames, promote sedentary behaviours that lead to overweight and obesity problems (Kohorst, Warad, Nageswara-Rao and Rodriguez, 2018). In this way, healthy behaviours such as an adequate diet, associated with the practice of physical activity, are associated with young people who do not offer problems with video games (Kohorst, Warad, Nageswara-Rao and Rodriguez, 2018).

\section{CONCLUSIONS}

Those young people who register more hours of sleep and more hours of physical activity, do not show problems with video games. However, the highest values of digital screen use are related to severe problems. 
Those students who do not have any problems with video games get higher values on an academic, emotional, family and physical level. In contrast, higher values of social self-concept are associated with severe problems.

Finally, higher body mass indexes are associated with severe problems with video games, while higher adherence to the Mediterranean diet is associated with those who do not have problems.

\section{REFERENCES}

Aguilar, M. M., Vergara, F. A., Velásquez, E. J., \& García-Hermoso, A. (2015). Actividad física, tiempo de pantalla y patrones de sueño en niñas chilenas. An Pediatr, 83(5) 304-310. https://doi.org/10.1016/i.anpedi.2014.12.006

Barr-Anderson, D. J., Cook, B., Loth, K., \& Neumark-Sztainer, D. (2018). Physical activity and sociodemographic correlates of adolescent exergamers. J Adolescent Health, 62(5), 630-632. https://doi.org/10.1016/j.jadohealth.2017.12.009

Chacón-Cuberos, R., Castro-Sánchez, M., González-Campos, G., \& Zurita-Ortega, F. (2018). Victimization in school, digital leisure and irritability: Analysis using structual equations. Rev Electron Investig Eval Educ, 24(1), 3-14.

Chacón-Cuberos, R., Muros-Molina, J.J., Cachón-Zagalaz, J., Zagalaz-Sánchez, M. L., Castro-Sánchez, M., \& Zurita-Ortega, F. (2018). Actividad física, dieta mediterránea, capacidad aeróbica y clima motivacional hacia el deporte en escolares de la provincia de Granada: Un modelo de ecuaciones estructurales. Nutr Hosp, 35(4), 774-781. https://doi.org/10.20960/nh.1511

Chacón-Cuberos, R., Zurita-Ortega, F., Castro-Sánchez, M., \& Espejo-Garcés, T. (2018). The association of Self-concept with Substance Abuse and Problematic Use of Video Games in University Students: A Structural Equation Model Relación entre autoconcepto, consumo de sustancias y uso problemático de videojuegos en universitarios. Adicciones, 30(3), 179-188. https://doi.org/10.20882/adicciones.872

Espejo-Garcés, T., Chacón-Cuberos, R., Castro-Sánchez, M., Zurita-Ortega, F., Martínez-Martínez, A., \& Pérez-Cortés, A. J. (2018). Incidencia del consumo de videojuegos en el autoconcepto académicofísico de estudiantes universitarios. Píxel-Bit. Rev Medios Educ, 52, 7-19. https://doi.org/10.12795/pixelbit.2018.152.01

Espejo-Garcés, T., Zurita-Ortega, F., Chacón-Cuberos, R., Castro-Sánchez, M., Martínez-Martínez, A., y Pérez-Cortés, J. A. (2018). Actividad física y autoconcepto: dos factores de estudio en adolescentes de zona rural. Rev Iberoamericana Psic Ejer Deporte, 13(2), 203-201.

Fuentes, M., García, J., García, E., \& Lila, M. (2011). Autoconcepto y ajuste psicosocial en la adolescencia. Psicothema, 23(1), 7-12.

González-Valero, G., Padial-Ruz, R., Espejo-Garcés, T., Chacón-Cuberos, R., Puertas-Molero, P., \& Pérez-Cortés, A. J. (2017). Relación entre clima motivacional hacia el deporte y adherencia a la dieta mediterránea en estudiantes universitarios de educación física. Int J Dev Educ Psychol., 4(1), 285-296. https://doi.org/10.17060/ijodaep.2017.n1.v4.1058

González-Valero, G., Ubago-Jiménez, J. L., Zurita-Ortega, F., Chacón-Cuberos, R., Castro-Sánchez, M., \& Puertas-Molero, P. (2018). Eating Habits and Lifestyles in Schoolchildren from Granada (Spain). A Pilot Study. Educ Sci, 8(4), 216. https://doi.org/10.3390/educsci8040216

González-Valero, G., Zurita-Ortega, F., Chacón-Cuberos, R., \& Puertas-Molero, P. (2019). Analysis of Motivational Climate, Emotional Intelligence, and Healthy Habits in Physical Education Teachers of the Future Using Structural Equations. Sustainability, 11(13), 3740. https://doi.org/10.3390/su11133740 
González-Valero, G., Ubago-Jiménez, J. L., Ramírez-Granizo, I. A., \& Puertas-Molero, P. (2019). Association between Motivational Climate, Adherence to Mediterranean Diet, and Levels of Physical Activity in Physical Education Students. Behav Sci, 9(4), 37. https://doi.org/10.3390/bs9040037

Graves, L., Stratton, G., Ridgers, N. D., \& Cable, N. T. (2007). Comparison of energy expenditure in adolescents when playing new generation and sedentary computer games: cross sectional study. Bmj, 335(7633), 1282-1284. https://doi.org/10.1136/bmi.39415.632951.80

Higuchi, S., Motohashi, I., Liu, I. \& Maeda, A. (2005). Efectos de jugar un juego de computadora usando una pantalla brillante en variables fisiológicas pre-sueño, latencia del sueño, sueño de onda lenta y sueño REM. J Sleep Res, 14 (3), 267-273.

Keller, P. S., Haak, E. A., DeWall, C. N., \& Renzetti, C. (2019). Poor sleep is associated with greater marital aggression: The role of self control. Behav Sleep Med, 17(2), 174-180. https://doi.org/10.1080/15402002.2017.1312404

Kohorst, M. A., Warad, D. M., Nageswara Rao, A. A., \& Rodriguez, V. (2018). Obesity, sedentary lifestyle, and video games: The new thrombophilia cocktail in adolescents. Pediatr Blood Cancer, 65(7), e27041. https://doi.org/10.1002/pbc.27041

McKay, M. T., Sumnall, H. R., Cole, J. C. \& Percy, A. (2012). Self-esteem and self-efficacy: Associations with alcohol consumption in a sample of adolescents in Northern Ireland. Drug-Educ Prev Polic, 19, 72-80. https://doi.org/10.3109/09687637.2011.579585

Mireku, M., Barker, M., Mutz, J., Dumontheil, I., Thomas, M., Rooli, M., Elliott, P., \& Toledano, M. (2019). Night-time screen-based media device use and adolescents'sleep and health-related quality of life. Environ Int, 124, 66-78. https://doi.org/10.1016/i.envint.2018.11.069

Ng, N., Fleming, T., Robinson, M., Thomson, B., Graetz, N., Margono, C., (2014). Global, regional, and national prevalence of overweight and obesity in children and adults during 1980-2013: a systematic analysis of the Global Burden of Disease Study 2013. Lancet 384(9945), 766-81.

Ogunleye, A., Voss, C., y Sandercock, G. R. (2014). Displacement of bedtime by screen time in achoolchildren: the importance of area deprivation. Pediatr Int, 6, 1-8.

Ramírez-Granizo, I. A., Sánchez-Zafra, M., Zurita-Ortega, F., Puertas-Molero, P., González-Valero, G., \& Ubago-Jiménez, J. L. (2020). Multidimensional Self-Concept Depending on Levels of Resilience and the Motivational Climate Directed towards Sport in Schoolchildren. Int. J. Environ. Res. Public Health (2), 534. https://doi.org/10.3390/ijerph17020534

Rosen, L.D., Lim, A.F., Felt, J., Carrier, L.M., Cheever, N.A., Lara-Ruiz, J.M., (2014). Media and technology use predicts ill-being among children, preteens and teenagers independent of the negative health impacts of exercise and eating habits. Comput Hum Behav 35, 364-75. https://doi.org/10.1016/i.chb.2014.01.036

San Román-Mata, S. (2019). Mediterranean diet and physical activity in young people and adults of Melilla. ESHPA. Educ Sport Health Phy Activ Inter J, 3(2), 209-222.

Solís-García, P., \& Borja-González, V. (2019). Niveles de actividad física y sedentarismo en escolares de $3^{\circ}$ y $4^{\circ}$ de Educación Primaria. EmásF, 10(59), 119-131.

Šporčić, B., \& Glavak-Tkalić, R. (2018). The relationship between online gaming motivation, self-concept clarity and tendency toward problematic gaming. Cyberpsychol J Psychosoc Res Cyberspace, 12(1). https://doi.org/10.5817/cp2018-1-4

Yen, C. F., Ko, C. H., Yen, J. Y., \& Cheng, C. P. (2008). The multidimensional correlates associated with short nocturnal sleep duration and subjective insomnia among Taiwanese adolescents. Sleep, 31(11), 1515-1525. https://doi.org/10.1093/sleep/31.11.1515

Zurita-Ortega, F., Ubago-Jiménez, J., Puertas-Molero, P., González-Valero, G., Castro-Sánchez, M., \& Chacón-Cuberos, R. (2018). Niveles de actividad física en alumnado de Educación Primaria de la 
provincia de Granada (Physical activity levels of Primary Education students in Granada). Retos, 0(34), 218-221. Retrieved from https://recyt.fecyt.es/index.php/retos/article/view/60098

\section{(c) $($ ) $९$}

This work is licensed under a Attribution-NonCommercial-NoDerivatives 4.0 International (CC BY-NC-ND 4.0). 